\title{
МОРФОМЕТРИЧНЕ ПОРІВНЯННЯ ГЛИБИНИ ШЛУНКОВИХ ЯМОК ПІСЛЯ ВИКОНАННЯ РІЗНИХ МЕТОДІВ РЕЗЕКЦІЇ ШЛУНКА
}

Вінницький національний медичний університет ім. М.І. Пирогова

Резюме. У статті представлені результати морфометрії після різних методів резекції шлунка із застосуванням клапанного механізму та без нього. Встановлено наявність морфологічних змін глибини шлункових ямок після проведення резекції шлунка за загальноприйнятою методикою Більрот-1 та Більрот-2. Проведена порівняльна оцінка застосування даних методів резекції шлунка та методів Більрот-1 та Більрот-2 з утво- ренням гастродуоденального клапана. Показана максимальна наближеність глибини шлункових ямок до показників контрольної групи тварин при резекції шлунка 3 формуванням гастродуоденального клапана.

Ключові слова: шлунок, шлункові ямки, гастроентеральний клапан.

органів шлунково-кишкового тракту (ШКТ). Потрете, ДПК повністю виключається 3 процесу травлення, тому постає питання про гістологічні зміни, які відбуваються в іiі пошаровій будові, особливо в слизовій оболонці [2].

Досить частим ускладненням $є$ неспроможність швів культі ДПК, одним із пояснень якого $\epsilon$ підвищення тиску в ДПК після видалення пілоруса [4]. Водночас залишаються дискусійними питання вибору форми шлункової кукси та ії̈ анастомозування 3 ділянкою тонкої кишки, яка б забезпечувала достатню резервуарну функцію та порційний характер евакуації. Відомо також, що руйнування пілоруса - одна з основних причин виникнення постгастрорезекційних розладів. Очевидно, формування, незалежно від способу РШ, гастродуоденального чи гастроентерального клапана дасть змогу створити умови для порційного пасажу хімусу та усунути певні патологічні синдроми.

Мета дослідження. Дослідити глибину шлункових ямок після виконання різних методів РШ.

Матеріал і методи. Дослідження проведені на 40 безпородних собаках віком 2-6 років (дозвіл комітету з біоетики, витяг 3 протоколу №3 від 18.11.05p.) Собак утримували в умовах віварію на звичайному харчуванні.

Для проведення експерименту всіх собак розподілено на чотири групи. Першій групі тварин виконували РШ за Б-1 за загальноприйнятою методикою - 10 собак. Другій групі тварин виконували РШ за Б-2 у модифікації ГофмейстераФінстерера за загальноприйнятою методикою 10 собак. Третій групі тварин виконували РШ за Б-1 з формуванням гастродуоденалього клапана за власною методикою - 10 собак (клапан формували із слизової оболонки шлунка, патент на корисну модель № 26180). Четвертій групі тварин виконували РШ за Б-2 у модифікації Гофмейстера-Фінстерера 3 формуванням гастроентерального клапана за власною методикою - 10 собак.

Після виконання різних методів РШ тварин поступово виводили з експерименту шляхом уведення летальної дози тіопенталу.

Результати дослідження та їх обговорення. Через три місяці після виконання РШ за Б-1 у 
першій групі тварин встановлено достовірне збільшення глибини шлункових ямок до $17,06 \pm 0,51$ мкм $\mathrm{p}<0,0004$, що в 1,2 раза більше від показників контролю (14,3 $\pm 0,61$ мкм). Через 12 місяців спостерігали тенденцію до підвищення глибини шлункових ямок до 20,5 $\pm 0,13$ мкм, $\mathrm{p}<0,0004$, що в 1,4 раза більше від показників контрольних тварин.

Більш виражені зміни спостерігали у тварин після РШ за Б-2 у модифікації ГофмейстераФінстерера. Через три місяці встановлено достовірне збільшення глибини шлункових ямок до $24,5 \pm 0,53$ мкм, $\mathrm{p}<0,0004$, що в 1,7 раза перевищувало такі в тварин контрольної групи (14,3 $\pm 0,61$ мкм). Через 12 місяців після експерименту глибина шлункових ямок достовірно збільшилась до $23,5 \pm 1,24$ мкм, $\mathrm{p}<0,0004$, що в 1,6 раза більше від контрольної групи тварин. Очевидно, дані зміни призвели до більш глибоких дизрегенераторних процесів, що, у свою чергу, стали поштовхом до структурної перебудови як поверхневого епітелію, так і залоз шлунка.

Проведені нами дослідження також дозволили дійти висновку, що гістологічні зміни в стінці шлунка менш виражені після формування клапанного апарату.

Через три місяці після виконання РШ за Б-1 iз моделюванням гастродуоденального клапана в шлунку спостерігали незначні дефекти епітелію слизової оболонки із серозним набряком та лейкоцитарною інфільтрацією. Глибина шлункових

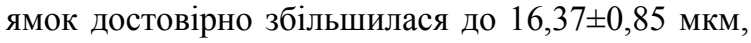
$\mathrm{p}<0,0004$, що в 1,1 раза була більшою відносно контрольної групи тварин (14,3 $\pm 0,61$ мкм). Через 12 місяців глибина шлункових ямок достовірно збільшилась до $15,81 \pm 0,75$ мкм, $\mathrm{p}<0,0002$, що в 1,2 раза більше від контролю (14,3 $\pm 0,61$ мкм).

При виконанні РШ за Б-2 із моделюванням гастроентерального клапана через три місяці після виконання експерименту глибина шлункових

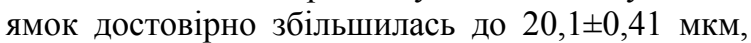
$\mathrm{p}<0,0004$, що в 1,4 раза більше від контрольної групи тварин (14,3 $\pm 0,61$ мкм). Через 12 місяців глибина шлункових ямок достовірно збільшилась до $22,78 \pm 0,531$ мкм, $\mathrm{p}<0,0004$, що в 1,6 раза більше відносно контролю.

У групі тварин, яким виконано РШ за Б-2 із моделюванням гастроентерального клапана, через 12 місяців відмічали наявність значної кількості лімфоїдних фолікулів у стані гострого запалення. Також відмічено розростання сполучно- тканинних перегородок між залозами шлунка та їх виражену гістіолімфоцитарну інфільтрацію, що була менше виражена порівняно з групою тварин, яким виконана РШ за Б-2 у модифікації Гофмейстера-Фінстерера без клапана.

Аналізуючи результати досліджень, можна дійти висновку, що у тварин, котрим була виконана РШ за Б-1 з моделюванням гастроентерального клапана, при морфометричному порівнянні глибини шлункових ямок та товщини слизової оболонки відмічена їх найбільша наближеність до даних контрольної групи тварин.

\section{Висновок}

Проаналізувавши результати морфометричних досліджень глибини шлункових ямок після різних методів резекції шлунка, слід відмітити, що найбільш доцільним є застосування резекції шлунка за Більрот-1 та Більрот-2 з утворенням гастродуоденального клапана. На доцільність застосування даного методу резекції шлунка вказують максимальна наближеність глибини шлункових ямок до контрольної групи тварин.

Перспективи подальших досліджень. Отримані результати вказують на необхідність подальших досліджень гістологічної будови клітин шлунка після різних методів резекції.

\section{Література}

1. Алиджанов Ф.Б. Тактика лечения острой кишечной непроходимости у больных, перенесших резекцию желудка / Ф.Б. Алиджанов, У.Р. Жамилов // Вестн. хирургии им. И.И. Грекова. - 2009. - № 2. - С. 87-89.

2. Дусик А.В. Морфологічні зміни в шлунку при портальній гіпертензії та при їі корекції формуванням спленоренального анастомозу / А.В. Дусик // Biomedical and Biosocial Anthropology. - 2009. - № 12. C. $149-152$

3. Меліссас Дж. Лапароскопічна рукавна резекція шлунка: досвід баріатричного відділення Університету Криту, Греція / Дж. Меліссас, М. Даскалакіс, І. Аскоксилакіс // Клін. хірургія. - 2012. - № 5. - С. 14-18.

4. Уваров И.Б. Первичная еюногастропластика с концево-петлевым гастроэнтероанастомозом и включением двенадцатиперстной кишки при дистальной резекции желудка (хирургическая технология и функциональные результаты) / И.Б. Уваров, С.Р. Генрих, Д.А. Лютов // Вестн. хирургии им. И.И. Грекова. - 2008. № 1. - C. $37-42$.

5. Шотт В.А. Технические приемы формирования желудочно-тощекишечного соустья при резекции желудка по Бильрот-ІІ / В.А. Шотт // Хирургия. - 2012. - № 1. - C. 25-28.

\section{МОРФОМЕТРИЧЕСКОЕ СРАВНЕНИЕ ГЛУБИНЫ ЖЕЛУДОЧНЫХ ЯМОК ПОСЛЕ РАЗНЫХ МЕТОДОВ РЕЗЕКЦИИ ЖЕЛУДКА}

\section{П.В. Жорняк}

Резюме. В статье представлены результаты морфометрических исследований глубины желудочных ямок после разных методов резекций желудка с внедрением гастроэнтерального клапана и без него. Доказано наличие морфологических изменений глубины желудочных ямок после проведения резекции желудка по Бильрот-1 и Бильрот-2 по общепринятой методике. Проведена сравнительная оценка применения данных методов резекции желудка и методов Бильрот-1 и Бильрот-2 с образованием гастродуоденального клапана. Показана максимальная приближен- 
ность глубины желудочных ямок к показателям контрольной группы животных при резекции желудка с формированием гастродуоденального клапана.

Ключевые слова: желудок, желудочные ямки, гастроэнтеральный клапан.

\title{
MORPHOMETRIC COMPARISON OF GASTRIC PITS DEPTH AFTER DIFFERENT METHODS OF GASTRECTOMY
}

\section{P.V. Zhorniak}

\begin{abstract}
The article presents the results of morphometric studies of the depth of gastric pits after different methods of gastrectomy with the introduction of gastroenteral valve and without it. It proved the presence of morphological changes in the depth of the pits after gastric resection Billroth-1 and Billroth-2 by the usual method. A comparative evaluation of the application of these methods and techniques of gastric resection Billroth-1 and Billroth-2 with the formation of gastroduodenal valve. It is shown that the maximum depth of the gastric pits proximity to that of the control group animals at gastrectomy with gastroduodenal valve formation.
\end{abstract}

Key words: the stomach, the gastric pits, gastroenteral valve.

Pyrohov National Medical University (Vinnytsia)

Рецензент - проф. В.П. Польовий

Buk. Med. Herald. - 2015. - Vol. 19, № 4 (76). - P. 63-65

Надійшла до редакції 08.10.2015 року

(c) П.В. Жорняк, 2015 